\title{
Eastern Cape teachers' beliefs of the nature of mathematics: implications for the introduction of in-service mathematical literacy programmes for teachers
}

\author{
Lyn Webb and Paul Webb \\ Department of Science, Mathematics and Technology Education, University of Port Elizabeth \\ Email: lyn.webb@upe.ac.za; paul.webb@upe.ac.za
}

\begin{abstract}
Various studies have shown that what teachers consider to be optimal ways of teaching mathematics is influenced by their beliefs about the nature of mathematics, and that it is advantageous to determine teachers' conceptions of the nature of mathematics before developing curriculum interventions. With the imminent introduction of Mathematical Literacy in the FET phase in South Africa this study provides a snapshot of beliefs of teachers in the Eastern Cape, South Africa. Various methods were employed to stimulate teachers to both reflect on their beliefs and to make them explicit. A questionnaire was administered to 339 in-service teachers in urban and rural areas of the Eastern Cape. A sample of ninetyfive of these teachers completed a second questionnaire based on videotapes of lessons recorded during the TIMSS (1995) study that they had viewed. These teachers also ranked their own teaching on a continuum ranging from traditional to constructivist approaches and provided explanations for their ranking. A further sub-sample of thirty-six teachers participated in individual interviews, which explored their perceptions of the nature of mathematics and their own teaching practice. In order to investigate whether these beliefs were mirrored in practice, four teachers were observed and videotaped in their classrooms. The data generated by this study suggest that the participating teachers' espoused beliefs of the nature of mathematics tended to be innovative, and correlated with innovative views of teaching and learning; however these views were often not reflected in their practice. The implications that the apparent inability of teachers to translate their beliefs into practice have for the introduction of a contextual, problem-based Mathematical Literacy curriculum for teachers is explored.
\end{abstract}

\section{Introduction}

In response to the proposed introduction of Mathematical Literacy in South African schools in 2006, the Eastern Cape Department of Education (ECDE) has been proactive in proposing that Higher Education Institutions (HEIs) in the Eastern Cape develop and deliver an Advanced Certificate in Education (ACE) in Mathematical Literacy. A consortium of seven HEIs has consulted and collaborated and the first cohort of teachers (identified by the ECDE) has been registered at each of the institutions. The teaching style for Mathematical Literacy, as expressed in the National Curriculum Statement of the Department of Education (DoE, 2003), is through contextual problem solving. This represents a change from traditional instructional practices employed in Eastern Cape classrooms, especially at the Further Education and Training (FET) level for grades 10, 11 and 12, where Outcomes Based Education has not yet been introduced.

Recent research publications, e.g., Chapman (2002), Hart (2002), Llinares (2002), Lloyd (2002), Philippou and Christou (2002), and Wilson and Cooney (2002), draw strong links between teachers' beliefs and teachers' practice and suggest that it is advantageous to determine teachers' conceptions of the nature of mathematics before developing curriculum interventions. This study investigated a sample of Eastern Cape teachers' beliefs about the nature of mathematics; how such beliefs were linked to these teachers' beliefs about teaching and learning; and whether espoused beliefs were mirrored in classroom practice, in order to ascertain whether these attitudes and practices were in line with those required for the introduction of a contextual, problem solving curriculum for Mathematical Literacy in South Africa.

\section{Theoretical Framework}

Thompson (1992) maintains that teachers differ a great deal in their beliefs about both the nature of mathematics and how they view the teaching and learning of mathematics. Teachers' conceptions of the nature of mathematics range from seeing mathematics as an absolute, fixed body of knowledge to viewing the discipline as a fallible and expanding human invention. Schoenfeld (1985) concludes that most students view 


\section{Eastern Cape teachers' beliefs of the nature of mathematics: implications for the introduction of in-service mathematical literacy programmes for teachers}

mathematics as a body of knowledge to be memorised, despite the fact that teachers often emphasise the importance of understanding the subject. Schoenfeld (1985) also notes that learners experience neither understanding nor a perception of utility of the subject in practice. These findings are supported by Morar's (2000) and Stoker's (2003) studies of teachers in South Africa who, despite professing beliefs in a constructivist paradigm, used traditional approaches that led learners to see mathematics as a subject to be memorised.

Views of the nature of mathematics can be seen on a continuum, from an 'absolutist' viewpoint in which mathematical truth is unquestionable, certain and objective at one pole, to a 'fallibilist' viewpoint, in which mathematical knowledge can be seen as a social construction and is therefore fallible (as it can be revised and corrected), at the other pole. Learning mathematics can also be represented on a continuum from mastery of skills to problem-solving, with the opposite poles of a continuum for teaching mathematics being represented by the notions of the teacher as instructor or the teacher as facilitator. (Lerman, 1986).

Ernest (1989) maintains that there are three philosophies of mathematics, i.e., instrumentalist, platonist and problem-solving views of mathematics. In the instrumentalist view mathematics is seen as a set of unrelated but utilitarian rules and facts. It is an accumulation of facts, rules and skills that are to be used in the pursuance of some external end. The platonist view of mathematics is that of a static, but unified body of certain knowledge. Mathematics is therefore discovered not created. The problem-solving view sees mathematics as a dynamic, continually expanding field of human creation, a cultural product, which is constantly being revised and constructed.

Ernest (1989) views mathematics as "a process of inquiry and coming to know, not a finished product, for its results are open to revision" (p. 250) and sees the above three philosophies as a hierarchy, with instrumentalism at the bottom and problem-solving at the top. He also links teachers' views of the nature of mathematics with their models of teaching and learning and maintains that teachers' conceptions of the nature of mathematics form their philosophy of teaching and learning mathematics, despite the fact that they may be unable to articulate their beliefs fully, as they are often implicitly held (Ernest, 1989).
Ernest (1989) theorises that the teacher who views the nature of mathematics as a problemsolving activity should act as a facilitator in the classroom, regard learning as an active construction of understanding, and possibly even see learning as an autonomous problem-posing and problem-solving activity. However, in his research he admits that there was a discrepancy and discontinuity between teachers' espoused beliefs and enacted practices, and suggests that the cause might be attributed to the negative effects of some social and educational contexts of teaching.

This investigation was an attempt to explore the views of Eastern Cape teachers concerning the nature of mathematics and to ascertain whether there was any correlation between their espoused views of learning and how they teach mathematics in their classrooms. The possible effect of the often deprived social and physical contexts in which many teachers in the Eastern Cape operate, on their ability to transfer new and appropriate beliefs into practice, are viewed as challenges for the effective development of any meaningful professional development programme in Mathematical Literacy that aims at meeting the demands of the National Curriculum Statement (DoE, 2003).

\section{Sample}

The sample of teachers in this study was drawn from almost exclusively black schools in East London, King William's Town, Kokstad, Lusikisiki, Port Elizabeth, Queenstown and Umtata in the Eastern Cape. The participating teachers were registered for under-graduate (BEd) and postgraduate (BEd Hons) programmes in science and mathematics education at the University of Port Elizabeth. All data were gathered during lecture contact sessions.

\section{Method}

Lerman (2002) cautions that a number of research studies start from the premise that espoused beliefs and teachers' practice are consistent, but that this is frequently not the case. Wilson and Cooney (2002) highlight the methodological weakness in presuming that questionnaires and interviews will reveal beliefs, or systems of beliefs, that determine a teacher's actions in the classroom. They note that there appears to be a shift away from purely 'penand-paper' or quantitative techniques towards a wider acceptance of qualitative research designs. Because of these caveats a mixed mode methodology was employed in this study. Data were generated by means of a 'traditional' pencil and paper Likert type questionnaire that was 


\section{Lyn Webb and Paul Webb}

administered to 339 teachers. The questionnaire was adapted from an amalgam of reliable tests (McGinnis, 1997; Raymond, 1997; Schoenfeld, 1985; Sibaya \& Sibaya, 1998; Warren \& Nisbet, 2000), but the vocabulary was simplified and amended as English was not the respondents' mother tongue. Although the data were viewed critically and sceptically with Lerman's caveat in mind, they were valuable in identifying positive correlations between the scores obtained in terms of teachers' views of the nature of mathematics, and their views about teaching and learning in this subject. These quantitative data were then complemented and supplemented by qualitative findings.

Ninety-five of the participating teachers viewed the Third International Mathematics and Science Study (TIMSS) videos of an American lesson and a Japanese lesson and wrote critically comparative essays about the teaching practices that they had seen. They also wrote reflective essays on their own teaching practice and rated their teaching on a scale from 1 (highly traditional) to 10 (highly innovative). Individual semi-structured interviews were conducted with thirty-six teachers and videotapes were made of four teachers in their classrooms to assess whether there was a link between their espoused beliefs and their enacted practices. The data sets were combined in an attempt to allow for reliable and valid inferences to be drawn.

\section{Results}

\section{Questionnaire}

The initial questionnaire was designed in order to ascertain a teacher's beliefs about the nature of mathematics (e.g. mathematics changes all the time, it is dynamic; mathematics is a set of rules, etc.); about learning mathematics (e.g. mathematics is a problem-solving activity; learning mathematics mostly involves memorising, etc.); and about teaching mathematics (e.g. mathematics teaching should be learner-centred; learners learn mathematics best when the teacher lectures to them, etc.). The resulting data were plotted on a continuum and graphed. The two ends of the continuum of the nature of mathematics were an absolutist stance (that mathematics is an abstract, unrelated collection of facts, rules and skills that is static, certain and unrelated to the real world) as opposed to a fallibilist stance (that mathematics is practical, connected, dynamic, creative and problem driven). As regards learning mathematics, the two ends of the continuum were deemed to be that learners learn individually and passively through memorisation as opposed to learners learning actively through discussion, co-operative learning and problem-solving. As regards teaching mathematics, teacher-centred lecturing of unconnected topics (where mastery of skills was emphasised) was balanced with co-operative, learner-centred methods (where understanding was emphasised). All three graphs were skewed towards innovative beliefs, something that could have been caused by the fact that the teachers had just recently been exposed to constructivist teaching philosophies during their courses at the University of Port Elizabeth (UPE). However, there was no statistically significant difference between the data generated by those teachers starting their second year of study and those starting their first year of study. There was a statistically significant positive correlation of $(0.60 ; \mathrm{p}<.05)$ between participating teachers' views on the nature of mathematics and their views on how mathematics is learned. Their beliefs concerning the nature of mathematics and the teaching of mathematics also correlated positively $(0.59 ; \mathrm{p}<.05)$ as did their views on how mathematics should be taught and how it is learned $(0.71 ; \mathrm{p}<.05)$. These data suggest that the participating teachers who viewed the nature of mathematics through fallibilist eyes believed that learning takes place actively and co-operatively and that the subject should be taught in a learnercentred way. Those who viewed the nature of mathematics as instrumentalist believed that learning takes place through mastering algorithms and skills and through teacher-dominated instruction. These correlations indicate that if institutions can guide teachers towards fallibilist beliefs this could result in teaching styles that promote problem-solving through real-life activities and constructivist learning as required in teaching the new mathematical literacy curriculum.

\section{Rating of their own teaching practice}

Ninety-five teachers rated their own teaching practice on a continuum from 1 (highly traditional) to 10 (highly innovative). The mean score was 5,49 with the minimum score being 3 and the maximum score being 8 . There are a number of reasons for this rather neutral response. It may be that teachers realised that, despite their espoused beliefs, their own teaching methods were still traditional in approach. It may be that they did not fully understand the tenets of constructivist learning, or perhaps they were not sure what constructivist teaching might look like. 


\section{Classroom visits}

Four teachers, whose questionnaire scores fell towards the fallibilist end of Lerman (1986) and Ernest's (1989) continuum of understanding of the nature of mathematics, were observed in their classrooms. Apart from their espoused fallibilist beliefs, these particular teachers were also chosen because their schools were situated in Port Elizabeth and were therefore easily accessible.

What became immediately clear during the classroom observations was that although in the questionnaire the teachers had professed to fallibilist beliefs about the nature of mathematics, their classroom practice was not learner-centred nor did they act as classroom facilitators. On the contrary all seemed to teach in 'instructor' mode, where the emphasis was on skills mastery and only correct performance was acceptable. There was no observed attempt to use learners' prior knowledge or to work from the concrete to the abstract. Although learners sat in groups there was no group interaction or whole class discussion. Questions posed required one-word answers that were chorused from the class. As such, there was little evidence that their espoused beliefs, as reflected in the questionnaire, were enacted in their classroom practices.

\section{Interviews and responses to the TIMSS video clips}

Each teacher interviewed $(n=36)$ stated that their views about the nature of mathematics, teaching and learning had changed over the period of their BEd studies at UPE as a result of being exposed to new ideas and concepts. Prior to the commencement of their studies they had neither been challenged to describe mathematics, nor to reflect on their current practice.

During the interviews, the participating teachers appeared to realise that there was a discontinuity between their own beliefs and classroom practices. In order to throw some light on the reasons for this mismatch they were asked why they felt this was the case. The reasons they expressed for not being able to implement effective teaching and learning strategies included deficient initial teacher training and the fact that they had no recourse to appropriate resources and on-going professional development to make their methods more successful. Other reasons offered were lack of control in the classroom, moving out of their comfort zones, syllabus and time constraints and lack of confidence in their mathematics content knowledge and pedagogical content knowledge.
However, the teachers' $(n=95)$ responses to the TIMSS video clips suggested that there might be other reasons contributing to the discontinuity between beliefs and practice. From the analysis of the data generated by the respondents' critical comparison of the TIMSS teacher practices it appears that they recognised that their own teaching practice was similar to that presented in the 'American model'. They were able to reflect on the shortcomings evident in both the American and the Japanese models, but were not able to discuss meaningfully in their essays methods that would have been more appropriate, and probably more successful, than the ones shown in the videos.

To a large degree the participating teachers were initially convinced that the American teacher was using more constructivist methods than the Japanese teacher. They commented in their essays that the most obvious indicator of constructivist practice that they observed was the fact that the American teacher's students were seated in groups and she moved among them giving individual attention. This was in contrast to their observations in their essays that the Japanese teacher stood in front of straight rows of students for the majority of the lesson. This suggests that the teachers in this study judged constructivist teaching and learning mainly by means of physical trappings. Their knowledge of constructivism appeared to be based on the forms, and not the practices, of the theory. However, through later discussion in lectures they were able to unpack the concept of problemsolving and active learning - with the teacher as a facilitator and not an instructor of algorithms. On reflection, the participating teachers were able to recognise and discuss in groups during a lecture that the American example relied on skills whereas the Japanese lesson emphasised understanding a single problem in depth.

The fact that many participating teachers were initially unable to distinguish between the exterior manifestations of constructivism (e.g. moving around the class and having individual teacherlearner dialogue) and were not able to recognise a contextual, problem-solving approach that draws on prior knowledge, as was demonstrated in the Japanese lesson, possibly throws some light on why discontinuities exist between teachers' classroom practices and their espoused belief in constructivist approaches to teaching and learning. This has important implications for the design and implementation of any ACE Mathematical Literacy programme for teachers that requires a problem-solving and contextual approach. 


\section{Lyn Webb and Paul Webb}

\section{Discussion}

The teachers in this study consistently expressed innovative views about the nature of mathematics and how this subject should best be taught and learned. However their practices did not mirror their espoused beliefs. These data support Stoker's (2003) contention that teachers in the Eastern Cape, South Africa, have learned the rhetoric but have not internalised the reality of constructivist approaches to teaching and learning. Stoker's (2003) conclusion is supported by Brodie (2001), who has shown that South African teachers can change considerably regarding mathematical knowledge and knowledge of pedagogy, but that they have difficulty in changing their teaching practice towards methods of engaging learners in a learner-centred approach. Lerman (1986) and Ernest (1989) have also found this to be the case in other parts of the world and both mention the gap between espoused and enacted beliefs.

Hoyles (1992) maintains that inconsistencies between beliefs and practices are accentuated when teachers are faced with an innovation, which in this case could be the introduction of a contextual, problem-solving approach to teaching a new subject. She introduces the idea of 'situated beliefs', where situations produce beliefs through activities that are dependent on context and culture. This concurs with Ernest's (1989) view that espoused beliefs pass through a filter of social constraints before they appear as enacted practices. Ensor (1998) supports this notion, purporting that beliefs are not stable across contexts, and that differences in social situations result in multiple positioning of teachers. She suggests that the repertoires of knowledge and skills that one acquires could be called 'beliefs', which in turn are foregrounded and backgrounded according to the context in which the person is operating at the time.

The notion of 'situated beliefs' (Hoyles, 1992), coupled with the compelling arguments of Chapman (2002), Hart (2002), Llinares (2002), Lloyd (2002), Philippou and Christou (2002) and Wilson and Cooney (2002), who draw strong links between teachers' beliefs and practices, suggest a two pronged approach for continuing professional development of mathematical literacy teachers. This involves identifying teachers' beliefs and understandings as well as identifying the social contexts and constructs that prevent espoused beliefs from being reflected in classroom practice.

Ernest (1989) states that changes in the key beliefs of teachers concerning the nature of mathematics, and the nature of mathematics teaching and learning, are connected to reflection and autonomy on the part of the teachers themselves. This study has shown that the teachers who participated in this study in the Eastern Cape do harbour beliefs about the nature of mathematics that tend towards fallibilism, and that there is a correlation between their views on the nature of mathematics, and how it is best taught and learned. This could be as a result of their being encouraged to reflect on their teaching practices during their studies. However, there is a clear disparity between their espoused beliefs and the enactment of these beliefs. As noted above, this is not unique to the Eastern Cape, as research has shown that this disparity occurs internationally (Ernest, 1989). Furthermore, there seems to be a degree of consensus among researchers that the disparity occurs because of social constructs (Ensor, 1998; Ernest, 1989; Hoyles, 1992; Lerman, 1986). The lack of depth of understanding of constructivist tenets by the teachers participating in this study, the possible constraints preventing teachers from enacting their beliefs, and their particular social and educational contexts in the Eastern Cape may be, or may not be, unique. However, what is clear is that the current paucity of data on these issues suggests that the contexts in which South African teachers find themselves, and how these contexts may possibly affect their ability to actualise their espoused beliefs, requires further research.

\section{Conclusion}

This study provides a snapshot of Eastern Cape teachers' beliefs. It is encouraging to note that their beliefs tend towards constructivist philosophies and progressive views on teaching and learning. The National Curriculum Statement (DoE, 2003) defines Mathematical Literacy as a subject that will be taught through contextual problem-solving. If teachers hold fallibilist views of the nature of mathematics they will be open to new curriculum interventions that encompass a problem-solving approach as they believe that it optimises learning.

Interventions that aim at encouraging teachers to reflect on their beliefs and practices and to become autonomous agents of change, like the ACE for Mathematical Literacy that is being developed in the Eastern Cape, are of vital importance in the changing South African educational landscape. However, if this type of intervention is to be successful, the educational and social constructs that prevent espoused beliefs from being reflected in classroom practice need to be identified by further research and addressed in 


\section{Eastern Cape teachers' beliefs of the nature of mathematics: implications for the introduction of}

in-service mathematical literacy programmes for teachers

order to enable improved classroom practice. Unless this is achieved, it is possible that the new constructivist orientated Mathematical Literacy curriculum for FET learners will not meet the expectation of producing far reaching and transformative consequences in South African education.

\section{Acknowledgements}

Appreciative acknowledgement is made to the South African-Netherlands Research Programme on Alternatives in Development (SANPAD) for financial support for this study, which forms a subset of a larger SANPAD research initiative on Science and Mathematics Teachers' Perceptions of the Nature of Science.

\section{References}

BRODIE, K., 2001, "Changing practices, changing knowledge: towards mathematics pedagogical content knowledge in South Africa", Pythagoras 54, pp. 17-25

CHAPMAN, O., 2002, "Belief structure and inservice high school mathematics teacher growth", in Leder, G., Pehkonen, E., \& Törner, G., eds, Beliefs: A Hidden Variable in Mathematics Education?, pp. 177-194, Netherlands: Kluwer Academic Publishers

DEPARTMENT OF EDUCATION, 2003, National Curriculum Statement Grades 10-12 (General), Mathematical Literacy, Pretoria: Government Printers

ENSOR, P., 1998, "Teachers' beliefs and the 'problem' of the social", Pythagoras 46/47, pp. 3-7

ERNEST, P., 1989, "The impact of beliefs on the teaching of mathematics", in Ernest, P., ed., Mathematics Teaching: The State of the Art, pp. 149-151, London: Falmer Press

HART, L., 2002, "A four year follow-up study of teachers' beliefs after participating in a teacher enhancement project", in Leder, G., Pehkonen, E., \& Törner, G., eds, Beliefs: A Hidden Variable in Mathematics Education?, pp. 161176, Netherlands: Kluwer Academic Publishers

HOYLES, C., 1992, "Illuminations and reflections - Teachers, Methodologies and Mathematics", in Proceedings of the Sixteenth PME Conference 3, pp. 263-286

LERMAN, S., 1986, Alternative Views of the Nature of Mathematics and their possible influence on the teaching of Mathematics, $\mathrm{PhD}$ dissertation: University of London

LERMAN, S., 2002, "Situating research on mathematics teachers' beliefs and on change", in Leder, G., Pehkonen, E., \& Törner, G., eds, Beliefs: A Hidden Variable in Mathematics Education?, pp. 233-243, Netherlands: Kluwer Academic Publishers

LLINARES, S., 2002, "Participation and reification in learning to teach: the role of knowledge and beliefs", in Leder, G., Pehkonen, E., \& Törner, G., eds, Beliefs: A Hidden Variable in Mathematics Education?, pp. 195-210, Netherlands: Kluwer Academic Publishers

LLOYD, G., 2002, "Mathematics teachers' beliefs and experiences with innovative curriculum materials. The role of curriculum in teacher development", in Leder, G., Pehkonen, E., \& Törner, G., eds, Beliefs: A Hidden Variable in Mathematics Education?, pp. 149-160, Netherlands: Kluwer Academic Publishers

MCGINNIS, J.R., 1997, "Development of an instrument to measure teacher candidates' attitudes and beliefs about the nature of and the teaching of mathematics and science", paper presented at annual meeting of National Association for Research in Science Teaching, Oakbrook

MORAR, T., 2000, "Evaluating the contribution of 2 key teachers to the systemic transformation of educational support and the professional development of their colleagues in the Eastern Cape Province", paper presented at annual SAAMSE conference, Port Elizabeth

PHILIPPOU, G. \& CHRISTOU, C., 2002, “A study of the mathematics teaching efficacy beliefs of primary teachers", in Leder, G., Pehkonen, E., \& Törner, G., eds, Beliefs: A Hidden Variable in Mathematics Education?, pp. 211-232, Netherlands: Kluwer Academic Publishers

RAYMOND, A., 1997, "Inconsistency between a beginning elementary school teacher's mathematics beliefs and teaching practice", Journal for Research in Mathematics Education 28(5), p 550

SCHOENFELD, A.H., 1985, "Students' beliefs about mathematics and their effects on mathematical performance: a questionnaire analysis", paper presented at the annual meeting of the American Educational Research Association, Chicago

SIBAYA, D. \& SIBAYA, P., 1998, "Black university students' beliefs about the nature of mathematics", Journal of Education and Training 19(2), pp 1-11

STOKER. J., 2003, An investigation of mathematics teachers' beliefs and practices 


\section{Lyn Webb and Paul Webb}

following a professional development intervention based on constructivist principle, unpublished PhD dissertation: Curtin University of Technology

THOMPSON, A.G., 1992, "Teachers' beliefs and conceptions: A synthesis of the research", in Grouws, D., ed., Handbook of Research on Mathematics Teaching and Learning, New York: Macmillan Publishing Company

THIRD INTERNATIONAL MATHEMATICS AND SCIENCE STUDY, 1995, National Center for Education Statistics. Institute of Education Sciences, Washington DC: Department of Education

WARREN, E. \& NISBET, S., 2000, Factors in primary school teachers' beliefs about mathematics and teaching and learning mathematics, paper presented at annual MERGAI Conference, Fremantle, Western Australia

WILSON, M., \& COONEY, T., 2002, "Mathematics teacher change and development. The role of beliefs", in Leder, G., Pehkonen, E., \& Törner, G., eds, Beliefs: A Hidden Variable in Mathematics Education?, pp. 127-147, Netherlands: Kluwer Academic Publishers

"That arithmetic is the basest of all mental activities is proved by the fact that it is the only one that can be accomplished by a machine."

Schopenhauer (1788-1860) 